\title{
Importance of Prosopis cineraria (L.) Druce as a Medicinal Plant: A Review.
}

\author{
Rancey Jain ${ }^{1 *}$ \\ *1 Student, \\ Department of Botany, \\ Bioinformatics and Climate Change Impacts \\ Management, \\ USSC, Gujarat University, \\ Ahmedabad
}

\author{
Swati Jayswal ${ }^{2}$ \\ 2 Research Scholar, \\ Department of Botany, \\ Bioinformatics and Climate Change Impacts \\ Management, \\ USSC, Gujarat University, \\ Ahmedabad
}

\author{
Bharat Maitreya $^{3}$ \\ ${ }^{3}$ Professor, \\ Department of Botany, \\ Bioinformatics and Climate Change Impacts Management, \\ USSC, Gujarat University, \\ Ahmedabad
}

Article DOI: https://doi.org/10.36713/epra4698

\begin{abstract}
Prosopis cineraria (L.) Druce (Family Leguminosae, Sub-family Mimosoideae) is known as "Khejri tree". It is a deep rooted, nitrogen fixing, multipurpose endemic tree to the hot deserts of India. It has been used since ancient times, particularly for medicinal purposes, traditionally and socially. Traditionally paste, gum, smoke from leaves and pods are applied for antidiabetic, anticancer, anti-inflammatory and antimicrobial purposes. Phytochemical component of Prosopis such as flavonoids, tannins, alkaloids, quinones or phenolic compounds demonstrate various biofunctions, such as analgestic, anthelmintic, antibiotic, antimetic, microbial antioxidant, antimalarial, anti-protozoal, antipustule and antiulcer activities. Dry pods of Prosopis cineraria are also known as sangria pods and it is the main part of Rajasthani dishes and also have a broader range of pharmaceutical applications like in pain, high cholesterol level, diabetes, an anemia, kidney and liver disorders. The Prosopis cineraria plays an important role in the socio-economic development of the farmers. The review explores the use of Prosopis cineraria across the all disciplines for its medicinal value and deals with cultivation, nutrition, commercial and prominent pharmacological properties of the "wonder tree".
\end{abstract}

KEYWORDS: - Prosopis cineraria, antimicrobial activity, phytochemicals, khejri tree, sangri pods, pharmacological properties.

\section{INTRODUCTION}

Prosopis cineraria belongs to mimosoideae subfamily, commonly known as "khejri" or "shami tree". It is also known as king of thar desert forest. It is an endemic tree which is majorly found in Rajasthan in India. Prosopis cineraria is a small tree, leaves are bipinnate, branches are thorned along the internodes. Flowers are small and yellow and seeds are pods. Prosopis cineraria indicates the presence of a deep-water table [ Vyas R.V. et al., 2017]. Dry pods of the Prosopis is the main part of Rajasthani dishes and it has also ancient medicinal properties which are helpful 
pharmaceutically [Vandana Pathak et al., 2017]. Unriped pods are nutritious and they are also used into making pickles [Vandana Pathak et al., 2017]. Prosopis cineraria has also play a historical part in Rajasthan. During India's Rajputana famine, many people's lives were spared using the sweetish bark as a food [Vyas R.V. et al., 2017]. The smoke of Prosopis cineraria leaves is also good for eye trouble. The bark tonic is also used for several diseases like asthma, bronchitis, leukoderma, piles and woundering of mind [P. Saritha et al., 2018]. Prosopis cineraria pods and leaves have anticancer, anti-diabetic, anti-inflammatory and antimicrobial properties. Stem and bark have antiinflammatory and antirheumatic properties too. The sangria pods contain various phytochemicals/phytoconstituents like alkaloids, carbohydrates, steroids, protiens, flavones, flavonoids and phenol etc. [Preeti Khandelwal et al., 2016]. The plant material works as one of the herbal remedies for snake bite and scorpion sting. Prosopis cineraria is the national tree of the United Arab Emirates where it is known as "ghaf" [Anirudh Khatri et al., 2010].

Classification of Prosopis cineraria: - (According to Bentham and Hoocker)

Kingdom: - Plantae

Sub Kingdom: - Phanerogames

Division: - Angiosperms

Class: - Dicotyledons

Sub-class: - Polypetalae

Series: - Calyciflorae

Order: - Rosales

Family: - Leguminosae (Fabaceae)

Genus: - Prosopis

Species: - Cineraria

\section{Pharmacological effects of Prosopis cineraria}

- Antioxidant activity: According to Abhishek Gupta et al., 2015, the presence of phenolic compound suggests that the polyphenolic content is responsible for the antioxidant activity exhibited by this plant. The wound healing activity of PCEE ((Prosopis cineraria ethanolic extract)) was studied using excision wound model and the extract showed the significant wound healing activity.

- Antibacterial activity: According to Indhiramuthu Jayshree et al., 2014, the presence of flavonoids and tannins are responsible for the antibacterial activity in Prosopis. The ethanolic extract showed the maximum activity against staphylococcus aureus and klebsiella pneumonia and the aqueous extract showed maximum inhibitory effect against proteus mirabilis.

- Antidiarrheal activity: According to Narendra Naik et al., 2012, the stem and bark in methanolic extract of the plant part was utilized to evaluate the antidiarrheal activity.

- Analgesic activity: Arvind Kumar et al., 2011, studied using tail immersion test and hot plate methods on rats. The ethanolic extract of root showed the presence of alkaloids, tannins and steroids. The presence of metabolites is responsible for the analgesic activity.

- Antihyperglycemic activity: Deepika Sharma et al., 2013, concluded that the Prosopis have abundant activity in lowering blood sugar level. Study showed that blood sugar level increase and body weight decrease in diabetic rats become normal when treated with the plant extract of Prosopis. Thus, Prosopis extract activates the surviving of the $\beta$-cells of the islets and reduce the blood sugar level by producing an insulinogenic effect.

- Anti-cancer activity: According to Sumathi sundaravadivelu et al., 2012, "cancer" is a disease in which a group of cell divides in uncontrolled manner with invasion and metastasis. The methanolic activity of the leaves of Prosopis cineraria (L.) Druce were used, which showed significant radical scavenging activity. The extract inhibited cell proliferation by inducing cell death and the extant of cell proliferation

- Antitumor activity: According to Maideen N. et al.,2011, study showed reduced glutathione when compared to liver tumor bearing animals. The leaves extract also increased the levels of mitochondrial enzymatic antioxidants superoxide dismutase, catalase and glutathione peroxidase and nonenzymatic antioxidants in Hydro-alcoholic extracts.

- Bronchodilatory activity: According to Pareek A. K., et al., 2015, concluded the plant extract shows concentration dependent relaxant effect on both carbachol and $\mathrm{K}^{+}$ induced contraction causes blockade of the $\mathrm{Ca}^{+}$channel hence it also provides the vasodilatory effect.

- Skeletal muscle relaxant: According to M. George et al., 2012, concluded by the study that Prosopis cineraria posses significant skeletal muscle relaxant activity and the activity is due to the presence of alkaloids, 
tannins and flavonoids which are present in the leaves extract.

- Anticonvulsant activity: According to V. Velmurugan et al., 2012, concluded by the study that the methanolic extract have good anticonvulsant activity. Prosopis cineraria shows good anticonvulsant activity against seizure induced maximum electro shock (MES) and Pentylenetetrazol in a dose dependent manner. Inhibition of the maximum electro shock is observed against generalized tonic-clonic and cortical focal seizure.

- Bronchodilator activity: According to Khalid Hussain Janbaz et al.,2012, concluded that Prosopis cineraria is used for the treatment of respiratory disease like asthma, cough and bronchitis. He used methanolic extract to test the bronchodilator activity on carbachol. The extract shows concentration dependent relaxant effect on both carbachol and $\mathrm{K}^{+}$induced contraction. The bronchodilator activity is due to the blockade of $\mathrm{Ca}^{+}$channel.

- Detoxifying Activity: According to Sivarathri Siva Rajesh et al.,2013, proposed the detoxification effect of the aqueous, methanol and petroleum ether extract of medicinal plant Prosopis cineraria against Naja naja. The aqueous bark extract of Prosopis cineraria has substantial antivenom potential. The aqueous extract with the dose of $14 \mathrm{mg} / \mathrm{kg}$ have ability to neutralize the lethal activity completely. Aqueous extract not causes any type of adverse effect that are most common with other detoxifier and antidotes.

- Activity against multidrug resistant and fungal strains: According to Rosina Khan et al., 2010, concluded the extract of the Prosopis shows significant activity against most of the recently investigated microbial strains. The phytoconstituents present in the plant play a major role and act like phytomedicine to act against microbes. The extract of the Prosopis act like a novel antibiotic and effect of the Prosopis is similar to the beoad spectrum antibiotics. The extract of the Prosopis does not produce any advers effect after administration. The various types of phytochemicals are responsible for activity against multidrug resistance.

\section{Current plant parts use:}

1. Fruits: Fruit known as "sangri" or "dry pod" is an important ingredient of Rajasthani dish which is well known as "Panchkuta". [Khandelwal Preeti et al., 2014].

2. Leaves: The smoke of leaves is good for eye troubles. Leaf paste is also applied on boils and blisters including mouth ulcer. [M.W. Islam et al., 2019].

3. Flowers: Prosopis cineraria flower is mixed with sugar and used during pregnancy as safeguard against miscarriage. [Shruti Malik et al., 2013].

4. Bark: Bark of the plant has sweetish taste. It is also prescribed for scorpion sting and snake bite. [Dhananjaya Seturaman Prabha et al., 2014].

5. Medicinal uses: Almost all parts have traditional medicinal applications especially used as rheumatism, antidepressant, antibacterial, anticancer, antidiarrheal and antioxidant.

6. Environmental: Tree grown middle of the desert which shows water index in desert. It is also increased soil fertility [Ashish Kumar Pareek et al.,2015].

\section{CONCLUSION}

The Prosopis cineraria plant is known as one of the medicinal plants. The different parts of plant are used for medicinal purposes or anti-oxidant, antidiabetic, anti-microbial, anti-bacterial and anti-cancer. Pharmaceutical studies use Prosopis cineraria for processing of medicines against anti-fertility. It is useful in soil fertilation process and also helpful to find water index in desert.

\section{REFERENCE}

1. Abhishek Gupta, Shikar Verma, Ashish Kumar Gupta, Meenu Jangra and Ravi Pratap (2015), Evalution of Prosopis cineraria (Linn.) Druce leaves for wound healing activity in rats, Annal of Pharma Research, Vol. 3(1), Page no. 73.

2. Anirudh Khatri, Anita Rathore and $U K$ patil (2010), Prosopis cineraria (L.) Druce: A boon plant of desert - An overview, International Journal of Biomedical and Advance Research, Vol. 1(5), Page no. 142.

3. Arvind Kumar, Sanjay Kumar Yadav, Satyawan Singh, S.N. Pandeya (2011): Analgrstic activity of Prosopis cineraria (L.) Druce, Journal of Applied Pharmaceutical Science, Vol. 1(8), Page no. 158160.

4. Ashish Kumar Pareek, Dr. Shivgarg, Manoj Kumar, Sardar Mal Yadav (2015), Prosopis cineraria: A gift of Nature for Pharmacy, International Journal of Pharma Science and Research (IJPSR), Vol. 6(6), Page no. 959-960. 
5. Deepika Sharma, Yash Paul Singla (2013): Evalution of antihyperglycemic and antihyperlipidemic activity of Prosopis cineraria (Linn.) in wistar rats, Journal of scientific and Innovative Research, Vol. 2(4), Page no. 751-758.

6. Dhananjaya Seturaman Prabha, Hans-Uwe Dahms, Prabha Malliga (2014), Pharmacological Potentials of phenolic compounds from Prosopis spp.- A Review, Journal of Coastal Life Medicine, Vol.2(11), Page no. 918-924.

7. Indhiramuthu Jayashree, D H. Geetha and M. Rajeshwari (2014), Anti-Bacterial Properties of Prosopis cineraria (L.) Druce, International Journal of Advances in Pharmacy Biology and Chemistry, Vol. 3(3), Page no. 752.

8. Khandelwal Preeti, Sharma Ram Avatar, Agarwal Mala (2015), Pharmacology, Phytochemistry and therapeutic application of Prosopis cineraria linn: A review, Journal of Plant Sciences, Vol. 3(1-1), Page No. 33-39.

9. Khalid Hussain Janbaz, sajjiad Haider, Imran, Muhammad Zia-Ul-Haq, Laura DeMartino and Vincenzo De Feo. (2012): Pharmacological Evalution of Prosopis cineraria (L.) Druce in Gastrointestinal, Respiratory and Vascular Disorders, Hindawi Publishing Corporation Evidence-Based Complementary and Alternative Medicine, Page no. 1-7.

10. M. George, Lincy Joseph, Abishika Sarma (2012): Antideperessant and skeletal muscle relaxant effects of the aqueous extract of the Prosopis cineraria, Brazilian Journal of Pharmaceutical Science, Vol. 48(3), Page No. 577-581.

11. M.W. Islam, N. A. Hassan, S. H. Bloukh, M. Shahwan and R. R. Bhandare (2019), Exploring the Literature on Prosopis cineraria linn. For Its Therapeutic Potential and Safety: A Review, International Research Journal of Pharmacy, Vol. 10(7), Page No. 1-6.

12. Mayank Kulshrestha, Manjul Pratap Singh (2019), Pharmacognostic Standardization and Hplc Fingerprinting of Prosopis cineraria: An Ayurveda Mentioned Plant, Pharmacognosy communications, vol. 9(1), Page No. 21-26.

13. Maideen N., Velayutham R., Manavalan G. (2011), Protective Activity of Prosopis cineraria against $N$ Nitrosodiethylamine induced liver tumors in accordance to mitochondrial lipid peroxidation, mitochondrial antioxidant and liver weight, Continental J pharm Sci., Vol. 5(2), Page no. 1-6.

14. Narendra Naik D., Ramesh Malothy, Rameshwara Reddy G., Bhupesh Choudary, Naadella Jayasri P., Elumalai A. (2012): Evalution of in-vivo antidiarehoel activity of Prosopis cineraria linn. Stem, bark, Internaional journal of biological and pharmaceutical research, Vol. 3(3), Page no. 3173019.

15. P. Saritha and U. Anitha Devi (2018), Cultural and Medicinal Properties of Telangana state tree jhammi chettu (shami tree) (Prosopis cineraria linn.), Vol. 18(1), Page no. 991-994.

16. Pareek A. K., Garg S., Kuma M. (2015), Prosopis cineraria: A Gift of nature for pharmacy international Journal of Pharma sci. res., Vol. 6(6), Page No. 958-964.

17. Preeti Khandelwal, R.A. Sharma and Mala Agarwal (2016), Phytochemical analyses of various parts of Prosopis cineraria, International journal of pharmacy chemistry, Vol. 2(1), Page no. 6-9.

18. Rosina Khan,Mohammad Zakir, Sadul H. Afaq, Abdul Latif, Asad U. Khan. (2010): Activity of solvent extracts of Prosopis spicigera, zingiber officinale and Trachyspermum ammi against multidrug resistant bacterial and fungal strains, $J$ Infect Dev Ctries, Vol. 4(5), Page no. 292-300.

19. Sumathi Sundaravadivelu (2012): Influence of curcuma Amada and Prosopis cineraria leaf extract in human breast cancer cell line, J.cancer sci ther, Vol. 4(10), Page no. 136.

20. Shruti Malik, Sonia Mann, Deepika Gupta and Rajinder K Gupta (2013), Nutraceutical Properties of Prosopis cineraria (L.) Druce Pods: A Component of "Panchkuta", Journal of Pharmacognosy and Phytochemistry, Vol. 2(2), Page No. 66-73.

21. Sivarathri Siva Rajesh, Veerayan Elango and Thirunavukkarusu sivaraman. (2013): In vivo studies on detoxifying actions of aqueous bark extract of Prosopis cineraria against crude venom from Indian cobra (Naja naja), Bangladesh $J$ Pharmacol, Vol. 8, Pagr no. 395-400.

22. V. Velmurugan, G. Arunachalam and $V$. Ravichandran (2012): Anticonvulsant Activity of Methanolic Extract of Prospis cineraria (Linn.) Druce, stem and Barks, International Journal of Pharm Tech Research, Vol. 4(1), Page No. 89-92.

23. Vandana Pathak and Pramod Kumar (2017), Phytochemical screening of Prosopis cineraria (L.) stem, bark and leaves, International Journal of Innovative Science and Research Technology, Vol. 2(8), page no. 306-316.

24. Vyas R.V., Jadeja B.A. and Mehta M. (2017), Phytochemical Analysis of Prosopis cineraria (L.) Druce bark and pod, Pharma Science Monitor, Vol. 8(4), Page no. 327-333. 